\title{
Genetic linkage analysis of 14 candidate gene loci in a family with autosomal dominant osteoarthritis without dysplasia
}

\author{
I Meulenbelt, C Bijkerk, F C Breedveld, P E Slagboom
}

TNO-PG, Gaubius

Laboratory,

Vascular and

Connective Tissue

Research, PO Box

2215, 2301 CE Leiden,

The Netherlands

I Meulenbelt

C Bijkerk

P E Slagboom

Department of

Epidemiology and

Biostatistics, Erasmus

University Medical

School, Rotterdam,

The Netherlands

C Bijkerk

Departments of

Rheumatology and

Internal Medicine,

University Hospital,

Leiden, The

Netherlands

I Meulenbelt

F C Breedveld

Correspondence to:

Dr Slagboom.

Received 5 March 1997 Revised version accepted for publication 23 May 1997
Department of

\begin{abstract}
The role of various gene loci was investigated in a family in which familial osteoarthritis (FOA), with onset at an early age, is transmitted as an autosomal dominant mendelian trait. The absence of clinical and radiographic signs of dysplasia and calcium pyrophosphate deposition disease (CPDD) indicates that the basic disease process in this family is osteoarthritis (OA). Genetic linkage analysis of 14 candidate genes resulted in the exclusion of 10 important genes (COL2A1, COL9A1, COL9A2, COL11A1, COL11A2, COMP, the CPDD region, CRTL-1, CRTM, and MMP3). Other relevant genes were not informative in this family. The candidate loci previously identified in FOA and heritable skeletal disorders associated with OA are clearly not involved in the development of the primary FOA phenotype in the family investigated, indicating genetic heterogeneity.

(F Med Genet 1997;34:1024-1027)
\end{abstract}

Keywords: linkage analysis; familial osteoarthritis; chondrodysplasia; candidate genes

Osteoarthritis $(\mathrm{OA})$ is a degenerative disease of the joints, characterised by degradation of the hyaline articular cartilage and remodelling of the subchondral bone with sclerosis. Genetic factors play a role in the aetiology of familial OA (FOA) with an early age of onset (20-40 year) in multiple joints.

Table 1 Candidate genes with associated disease used for linkage analysis

\begin{tabular}{lll}
\hline Gene & Associated disease & Reference \\
\hline COL2A1 & Several types of chondrodysplasia, FOA ${ }^{\star}$, Stickler syndrome & $2-7$ \\
COL9A1 & OA, mild chondrodysplasia in mice & 89 \\
COL9A2 & EDM2† & 1011 \\
COL9A3 & - & - \\
COL11A1 & Stickler syndrome, chondrodysplasia in mice & 1213 \\
COL11A2 & Stickler/Kniest dysplasia, osteochondrodysplasias & 1415 \\
DCN & - & - \\
CRTL1 & - & - \\
COMP & PSACHł, EDM1§ & 1617 \\
CRTM & - & - \\
CCAL2 & Familial CPDD \| & 18 \\
LOX & Ehlers-Danlos type IX & 19 \\
PLOD & Ehlers-Danlos type VI & 2021 \\
MMP3 & - & -
\end{tabular}

COL2A $1=\alpha 1$ collagen type II gene. COL9A1 $=\alpha 1$ collagen type IX gene. COL9A2 $=\alpha 2$ collagen type IX gene. COL9A3= $\alpha 3$ collagen type IX gene. COL11A1= $\alpha 1$ collagen type XI gene. COL11A2 $=\alpha 2$ collagen type XI gene. $\mathrm{DCN}=$ decorin gene. $C R T L-1=$ cartilage link protein gene. $\mathrm{COMP}=$ cartilage oligomeric protein gene. $\mathrm{CRTM}=$ cartilage matrix gene. CCAL2=locus of familial chondrocalcinosis. LOX=lysyl oxidase gene. PLOD=lysyl hydroxylase gene. $M M P 3=$ stromelysin I gene. ${ }^{\star} F O A=$ familial osteoarthritis. $† E D M 2=$ multiple epiphyseal dysplasia type 2. $¥ P S A C H=$ pseudoachondrodysplasia. $囚 E D M 1=$ multiple epiphyseal dysplasia type 1 . $\| \mathrm{CPDD}=$ calcium pyrophosphate dihydrate deposition disease.
Research into the genetic loci involved in FOA has so far mainly been focused on the type II procollagen gene (COL2A1). The COL2A1 gene encodes the major stress resisting element and the most abundant structural collagenous protein in cartilage. ${ }^{1}$ Genetic studies of families and unrelated patients with an FOA phenotype accompanied by mild spondyloepiphyseal dysplasia (SED) have shown linkage to COL2A1 and mutations in the gene in approximately $25 \%$ of the cases. ${ }^{2}$ However, only a few studies have focused on families where OA is the only and primary disease process without any dysplasia. Genetic studies showed positive linkage to COL2A1 in two such FOA families. ${ }^{34}$ Mutation analysis of the COL2A1 gene in 45 unrelated FOA patients showed only one COL2A1 mutation. ${ }^{5}$ Studies on other candidate genes have not been reported for FOA. Genes, however, identified in heritable skeletal disorders associated with generalised OA may also play a possible role in FOA (table 1).

We have investigated the role of 14 candidate genes for FOA in a four generation Dutch family of Jewish descent in which the pedigree included 21 persons (fig 1). Informed consent and complete medical history was obtained for all family members. The study was approved by the Medical Ethics Committee of the Academic Hospital Leiden. Physical examinations were performed on all members of the third generation and on seven out of 14 direct descendants in the fourth generation. All clinical evaluations and diagnostic decisions were made before the genetic linkage analyses.

The family included many members affected with OA with an age of onset between 20 and 40 years. Symptoms began with intermittent acute pain and swelling in one or both knee joints with subsequent development of $\mathrm{OA}$ in other joints. The hip was only rarely affected (table 2). Radiographic signs of chondrodysplasia, spinal dysplasia, or abnormal development of the epiphyses of the peripheral joints were absent (fig 2). Some subjects had marked Heberden nodes (table 2, fig 3). The mean ratio of upper to lower segment of affected members was 0.95 (range 0.89 to 1.02), indicating the absence of a short trunk form of dysplasia. All family members had normal stature (table 2). The diagnosis was "pure" familial OA transmitted as an autosomal dominant mendelian trait (fig 1, table 2).

Genetic linkage analysis was performed using either intragenic or closely linked 
markers to the candidate genes (table 3). Genomic DNA samples of family members were collected by mouth swabs. ${ }^{37}$ All markers, except D20S19, were analysed by genomic PCR containing $\alpha[32 \mathrm{P}]-\mathrm{dCTP}{ }^{38}$ Alleles were separated by standard electrophoresis through

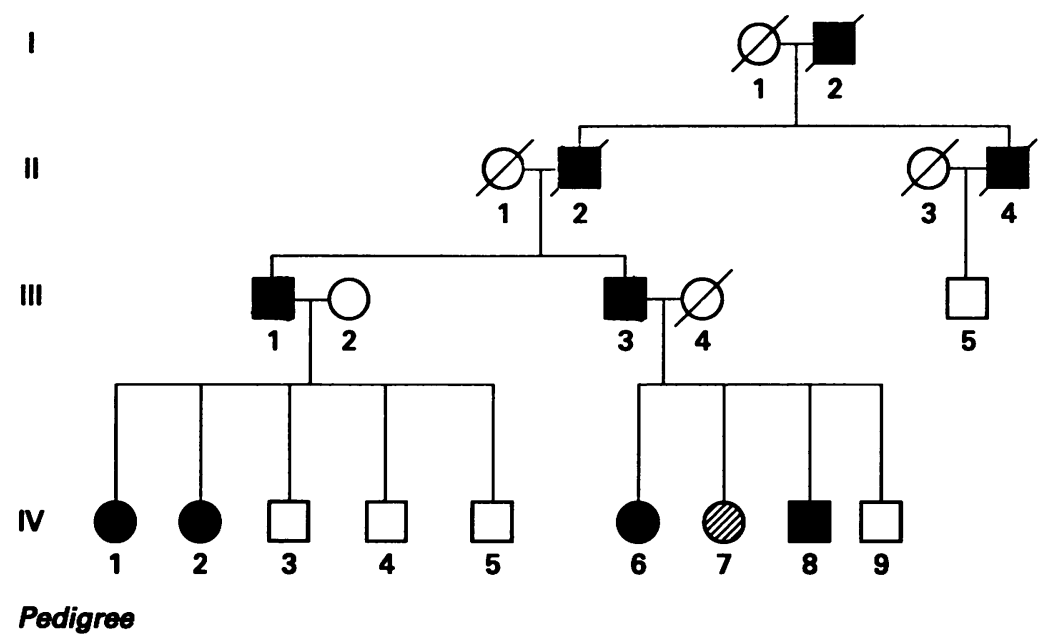

Figure 1 Pedigree of the FOA family used for linkage analysis. The hatched symbol represents diagnostic uncertainty, the filled symbols represent affected subjects.
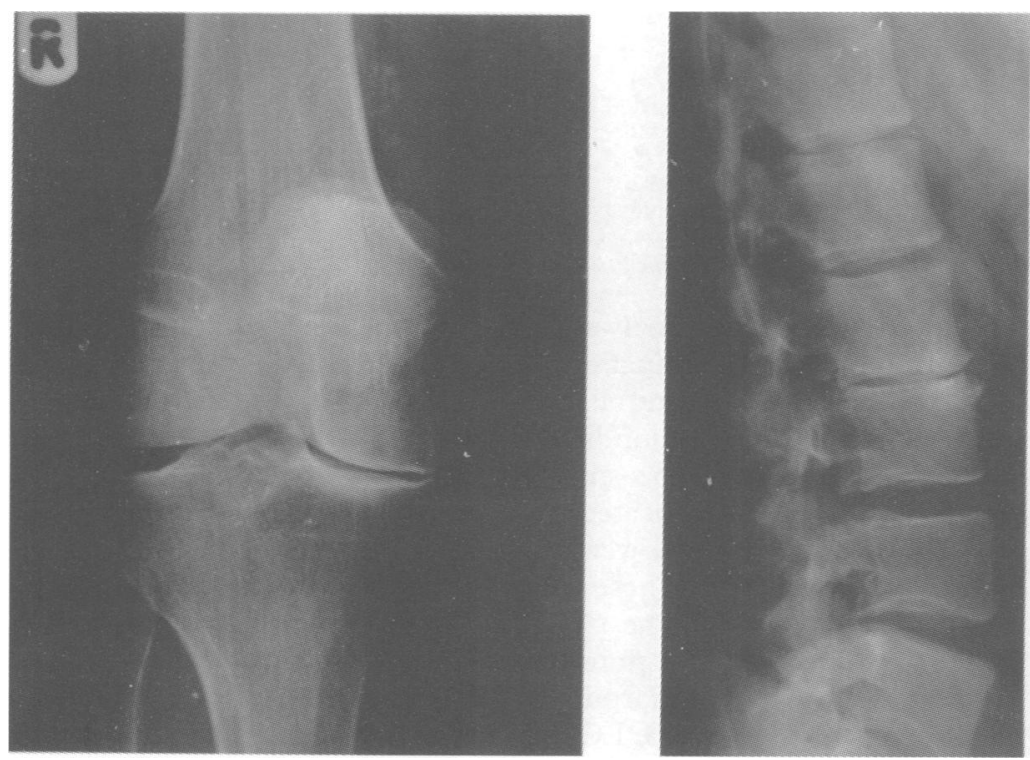

Figure $2 X$ rays of III. 1 aged 53 years. (A) Right knee joint showing marked $O A$ medially and chondrocalcinosis laterally, without evidence of epiphyseal dysplasia. (B) Lumbosacral spine joints (lateral view) showing osteophytosis and discus degeneration at level L2-L3. No dysplastic features. a denaturing polyacrylamide gel (3.5-6\%) and visualised by autoradiography. ${ }^{38}$ Alleles of marker D20S19 were analysed by Southern blotting and hybridisation with the clone pCMM20 radioactively labelled with $\alpha[32 \mathrm{P}]-\mathrm{dCTP}$. $^{38}$

Two point lod scores between the disease phenotype of family members and the markers were calculated using MLINK from the LINKAGE package version 5.1. ${ }^{39}$ Multipoint lod score analysis was performed using the LINKMAP program. ${ }^{40}$ The disease locus was modelled as an autosomal dominant trait. People with clinical and radiographic evidence of OA in two or more joints were considered affected. Penetrance was modelled to rise linearly from $0 \%$ at age 15 to $100 \%$ at 40 years,

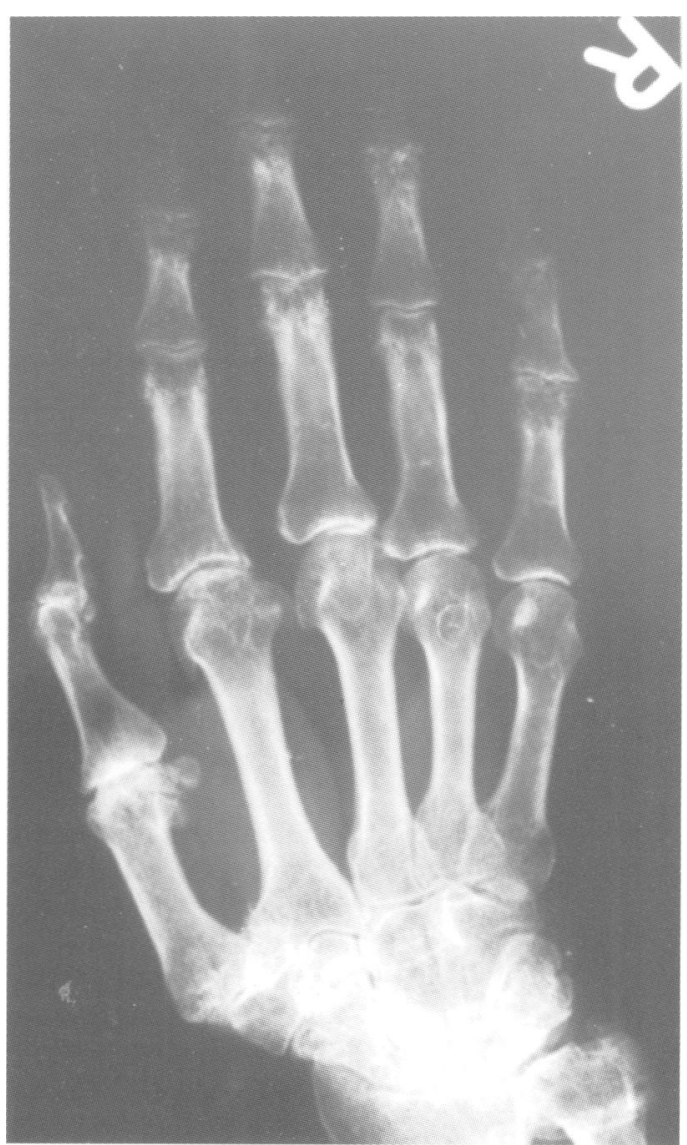

Figure $3 X$ ray of III. 3 aged 65 years showing hand joints with marked $O A$ in DIP, PIP, CMC1, MCP-I, and II. Heberden and Bouchard nodes are visible.

Table 2 Radiographic and clinical abnormalities in members of a family with autosomal dominant FOA

\begin{tabular}{|c|c|c|c|c|c|c|c|c|c|c|c|c|c|c|c|c|c|}
\hline $\begin{array}{l}\text { Patient } \\
\text { (age) }\end{array}$ & $M / F$ & $D I P$ & $P I P$ & $M C P$ & $C M C 1$ & Elbow & Shoulder & Hip & Knee & Foot & Ankle & $C S$ & $L S$ & No & $B M I$ & Height & $U / L$ \\
\hline II.2(一) & $M$ & - & - & - & - & $\mathrm{OA}$ & - & $\mathrm{N}$ & OA,C & OA & OA & - & - & 4 & & & \\
\hline III.1(73) & M & $\mathbf{P}, \mathrm{H}$ & - & - & OA & $\mathrm{OA}, \mathrm{C}$ & OA & - & $\mathrm{OA}, \mathrm{C}$ & OA & OA & OA & $\mathrm{OA}$ & 9 & 26.8 & 1.76 & 1.02 \\
\hline III.3(70) & M & $\mathrm{OA}, \mathrm{H}$ & OA,B & & OA & $\mathrm{P}$ & - & - & $\mathrm{OA}, \mathrm{C}$ & - & OA & OA & - & 9 & 24.3 & 1.64 & 0.96 \\
\hline III.5(67) & $\mathbf{M}$ & - & $\bar{T}$ & - & - & - & - & $\mathbf{N}$ & - & - & - & OA & $\mathrm{OA}$ & 2 & & & \\
\hline IV.1(42) & $\mathrm{F}$ & $\mathrm{N}$ & $\mathbf{N}$ & $\mathbf{N}$ & OA & - & - & - & OA & - & $\mathrm{N}$ & OA & OA & 4 & 26.3 & 1.70 & 0.83 \\
\hline IV.2(41) & $\mathrm{F}$ & & & & $\mathbf{N}$ & $\mathbf{N}$ & - & - & $\mathrm{OA}, \mathrm{C}$ & - & $\mathbf{P}$ & $\mathrm{OA}$ & - & 3 & 23.4 & 1.68 & 0.95 \\
\hline IV.3(39) & M & - & - & $\bar{M}$ & - & - & - & - & - & - & - & - & - & 0 & & 1.76 & \\
\hline IV.4(37) & $M$ & $\mathbf{N}$ & $\mathbf{N}$ & $\mathbf{N}$ & $\mathbf{N}$ & - & - & $\mathbf{N}$ & $\mathrm{N}$ & - & - & - & - & 0 & & 1.80 & \\
\hline IV.5(35) & $\mathbf{M}$ & - & - & $\bar{M}$ & - & - & - & $\mathbf{N}$ & $\mathbf{N}$ & - & - & - & - & 0 & & 1.76 & \\
\hline IV.6(42) & $\mathbf{F}$ & $\mathbf{N}$ & $\mathbf{N}$ & $\mathbf{N}$ & OA & - & - & $\mathbf{N}$ & OA & - & - & OA & & 3 & & & \\
\hline IV.7(40) & $\mathbf{F}$ & - & - & - & - & $\bar{T}$ & - & - & - & - & - & OA & - & 1 & & & \\
\hline IV.8(38) & $M$ & - & & - & - & $\mathbf{N}$ & - & - & $\mathrm{OA}, \mathrm{C}$ & OA & $\mathbf{N}$ & $\mathrm{OA}$ & $\mathbf{N}$ & 3 & 27.5 & 1.71 & 0.91 \\
\hline IV.9(27) & $\mathbf{M}$ & - & & - & - & & - & - & - & - & - & - & - & 0 & 22.4 & 1.83 & 0.91 \\
\hline
\end{tabular}

$\mathrm{M} / \mathrm{F}=$ male/female. $\mathrm{DIP}=$ distal interphalangeal joints. $\mathrm{PIP}=$ proximal interphalangeal joints. $\mathrm{MCP}=$ metacarpophalangeal joints. $\mathrm{CMC1}=$ first carpometacarpal joints. $\mathrm{CS}=$ cervical spine joints. $\mathrm{LS}=$ lumbar spine joints. No=number of joints affected with radiographic/clinical OA. BMI=body mass index. $\mathrm{U} / \mathrm{L}=$ upper/lower segment mal joint on both sides (Kellgren 0 or 1). $C=$ radiographic chondrocalcinosis. $P=$ clinical signs of $O A$ (bony enlargements/joint deformity/limited range of movement). $\mathrm{H}=$ Heberden's nodes. B=Bouchard's nodes. 
Table 3 Chromosomal location of candidate genes with polymorphic markers used for linkage analysis

\begin{tabular}{|c|c|c|c|c|}
\hline Gene & Location & Marker & $\begin{array}{l}\text { Distance (Kosambi cM) between } \\
\text { marker and gene }\end{array}$ & Reference \\
\hline COL2A1 & $12 \mathrm{q} 12-\mathrm{q} 13.2$ & VNTR & $0 \mathrm{KcM}$ & 22 \\
\hline COL9A1 & $6 q 12-q 14$ & $8 \mathrm{~B} 1$ & Intragenic & 23 \\
\hline COL9A2 & $1 \mathrm{p} 32.3-\mathrm{p} 33$ & MYCL1 & $0.2 \mathrm{KcM}$ & 2425 \\
\hline COL9A3 & $20 \mathrm{q} 13.3$ & D20\$19 & $5 \mathrm{KcM}$ & 2627 \\
\hline COL11A1 & ip21 & 7B1 & Intragenic & $\star$ \\
\hline COL11A2 & $6 \mathrm{p} 21.3$ & TNF locus; D6S291 & Map element $3.5 \mathrm{KcM}$ & $28-30$ \\
\hline DCN & $12 \mathrm{q} 21.3-\mathrm{q} 23$ & Dinucleotide intron $1 \mathrm{~A}$ & Intragenic & 31 \\
\hline CRTL1 & $5 q 13-q 14.1$ & Dinucleotide promoter & Intragenic & 32 \\
\hline COMP & $19 \mathrm{q} 12$ & D19S212 & $0.8 \mathrm{KcM}$ & 29 \\
\hline CRTM & $1 \mathrm{p} 35$ & $\begin{array}{l}\text { Dinucleotide 3' UTR } \\
\text { D1S247; D1S513 }\end{array}$ & $\begin{array}{l}\text { Intragenic } \\
\text { Map element } 2 \mathrm{KcM}\end{array}$ & 33 \\
\hline CCAL2 & $8 q$ & D8S545 & $0 \mathrm{KcM}$ & 29 \\
\hline LOX & $5 \mathrm{q} 23.3-\mathrm{q} 31.2$ & RFLP exon 1 (Pst I) & Intragenic & 34 \\
\hline PLOD & $1 \mathrm{p} 36.3-\mathrm{p} 36.2$ & FRG (1p36.2-p36.1) & $15 \mathrm{KcM}$ & 35 \\
\hline MMP3 & $11 \mathrm{q} 22-\mathrm{q} 23$ & D11S35 & $2 \mathrm{KcM}$ & 36 \\
\hline
\end{tabular}

*Personal communication, $M$ Warman.

Table 4 Two point lod scores calculated between familial osteoarthritis (FOA) and markers within or flanking the candidale gene loci

\begin{tabular}{|c|c|c|c|c|c|c|c|c|c|}
\hline \multirow[b]{2}{*}{ Genes } & \multicolumn{8}{|c|}{ Recombination fraction $(\theta)$} & \multirow{2}{*}{$\begin{array}{l}\text { Exclusion } \\
(K c M)^{\star}\end{array}$} \\
\hline & 0.00 & 0.001 & 0.01 & 0.05 & 0.1 & 0.2 & 0.3 & 0.4 & \\
\hline COL2A1 & $-\infty$ & -2.01 & -1.02 & -0.39 & -0.17 & -0.03 & -0.00 & -0.01 & 0.1 \\
\hline COL9A1 & $-\infty$ & -1.96 & -0.97 & -0.31 & -0.08 & 0.05 & 0.04 & -0.00 & 0.1 \\
\hline COL9A2 & $-\infty$ & -4.86 & -2.86 & -1.47 & -0.88 & -0.35 & -0.11 & -0.01 & 2.7 \\
\hline COL9A3 & $-\infty$ & -1.86 & -0.87 & -0.20 & 0.04 & 0.18 & 0.15 & 0.06 & 0.1 \\
\hline COL11A1 & $-\infty$ & -2.85 & -1.85 & -1.14 & -0.81 & -0.44 & -0.20 & -0.06 & 0.7 \\
\hline COL11A2 & $-\infty$ & -1.81 & -0.81 & -0.14 & 0.10 & 0.21 & 0.24 & 0.24 & 0.1 \\
\hline $\mathrm{DCN}$ & 0.41 & 0.41 & 0.40 & 0.37 & 0.31 & 0.20 & 0.10 & 0.03 & - \\
\hline CRTI.1 & $-\infty$ & -4.29 & -2.31 & -0.99 & -0.49 & -0.11 & 0.01 & 0.03 & 1.4 \\
\hline COM & $-\infty$ & -4.90 & -2.90 & -1.51 & -0.94 & -0.41 & -0.16 & -0.04 & 2.8 \\
\hline CRTM & -0.01 & -0.00 & -0.00 & 0.01 & 0.01 & 0.01 & 0.01 & 0.00 & - \\
\hline $8 q$ & $-\infty$ & -3.38 & -2.33 & -1.42 & -0.92 & -0.40 & -0.14 & -0.02 & 1.9 \\
\hline LOX & 0.36 & 0.36 & 0.35 & 0.30 & 0.25 & 0.15 & 0.07 & 0.02 & - \\
\hline PLOD & $-\infty$ & -5.05 & -3.05 & -1.63 & -1.02 & -0.45 & -0.17 & -0.04 & 3.3 \\
\hline MMP3 & $-\infty$ & -4.85 & -2.85 & -1.47 & -0.90 & -0.39 & -0.15 & -0.04 & 2.7 \\
\hline
\end{tabular}

ॠThe excluded distance is calculated with odds of 100:1 against linkage in Kosambi centiMorgans (KcM).

based on the onset age of OA as described previously. ${ }^{3}$ Subjects with ages of onset above 40 years were considered as phenocopies.

Lod scores and the recombination fractions yielding a lod score of -2 are shown in table 4 . Since the lod scores over the genetic region covered by the COL2A1, COL9A1, COL9A2, COL11A1, CRTL-1, COMP, CPDD, and MMP3 genes are $\leqslant-2$ (odds 100:1 against linkage), these genes were excluded from being involved in causing FOA in this family. The COL9A3, COL11A2, DCN, CRTM, LOX, and PLOD genes could not be excluded by two point linkage analysis (table 4). The COL11A2 and CRTM genes were excluded (lod scores $\leqslant-2$, table 5 ) by using multipoint lod score

Table 5 Multipoint lnd score analysis of disease locus (1) versus map element of polymorphic markers (2 and 3)

\begin{tabular}{llll}
\hline $\begin{array}{l}\text { COL11A2 } \\
1=2=3\end{array}$ & Lod score & $\begin{array}{l}\text { COL11A2 } \\
2=1=3\end{array}$ & Lod score \\
\hline 0.5000 .035 & 0.00 & 0.0000 .035 & $-\infty$ \\
0.4000 .035 & 0.05 & 0.0070 .028 & -2.56 \\
0.3000 .035 & 0.17 & 0.0140 .022 & -2.08 \\
0.2000 .035 & 0.26 & 0.0210 .015 & -2.08 \\
0.1000 .035 & 0.22 & 0.0280 .007 & -2.26 \\
0.0000 .035 & -15.12 & 0.0350 .000 & $-\infty$ \\
\hline CRTM & & $C R T M$ & \\
$1=2=3$ & Lod score & $2=1=3$ & Lod score \\
\hline 0.5000 .020 & 0.00 & 0.0000 .020 & $-\infty$ \\
0.4000 .020 & 0.00 & 0.0040 .016 & -3.83 \\
0.3000 .020 & -0.10 & 0.0080 .012 & -3.23 \\
0.2000 .020 & -0.36 & 0.0120 .008 & -2.88 \\
0.1000 .020 & -0.96 & 0.0160 .004 & -2.63 \\
0.0000 .020 & -32.22 & 0.0200 .000 & -2.43 \\
\hline
\end{tabular}

${ }^{\star}$ Computed by division of the location scores with $2 \ln (10)$. analysis with fixed markers and known recombination fractions (table 3). For the COL9A3 and PLOD genes, the excluded region surrounding the highly polymorphic markers was too small to exclude the genes. The markers located within the DCN and LOX genes (table 3) were not informative in important meioses. These genes could, therefore, not be excluded. The COL9A3 and DCN loci are mapped in regions containing too few alternative polymorphic markers and the genetic location of the LOX and PLOD genes is not well defined.

In summary, 10 genes were excluded from involvement in FOA in this family. Among these loci were important candidate genes involved in several heritable skeletal disorders, mild chondrodysplasia and epiphyseal dysplasia associated with early onset $O A$ in multiple joints (COL2A1, COL9A1, COL9A2, COL11A1, COL11A2, COMP, and the CPDD region). Other possible candidate genes encoding noncollagenous structural components, or genes involved in post-translational modification and remodelling of cartilage, were also excluded (CRTL-1, CRTM, and MMP3). The COL9A3, DCN, LOX, and PLOD genes could not be excluded as the cause of FOA in our family.

We have shown once more that FOA is genetically heterogeneous and that 10 important OA candidate genes are not involved in the pathogenesis of an FOA phenotype without dysplasia. Unidentified genes may be detected in future studies of this and other families in which FOA is the primary disease process. 
We would like to thank Dr J K van der Korst, Dr P J J M Rompa, and Professor Dr J J Rasker for providing us with the $x$ rays and medical histories of their patients, Saskia de Wildt for technical support, and Dr M Warman and Dr C J Williams for helpful discussions. This work was supported by the TNO-Health Organisation, the "Dutch League against Rheumatism" of the Netherlands, and Looscofoundation.

1 Prockop DJ, Kivirikko KI. Collagens: molecular biology, diseases, and potentials for therapy. Annu Rev Biochem 1995;64:403-34

2 Williams CJ, Jimenez SA. Heritable diseases of cartilage caused by mutations in collagen genes. If Rheumatol 1995;22(suppl 43):28-33.

3 Palotie A, Väisänen P, Ott J, et al. Predisposition to familial osteoarthrosis linked to type II collagen gene. Lancet 1989; i:924-7.

4 Vikkula M, Palotie A, Ritvaniemi P, et al. Early-onset osteoarthritis linked to the type II procollagen gene. Arthritis Rheum 1993;36:401-9.

5 Ritvaniemi P, Körkkö J, Bonaventure J, et al. Identification of COL2A1 gene mutations in patients with chondrodysplasias and familial osteoarthritis. Arthritis Rheum 1995;38: 999-1004.

6 Pun YL, Moskowitz RW, Lie S, et al. Clinical correlations of osteoarthritis associated with a single-base mutation (arginine ${ }^{519}$ to cysteine) in type II procollagen gene. Arthritis Rheum 1994;37:264-9.

7 Williams CJ, Rock M, Considine E, et al. Three new point mutations in type II procollagen (COL2A1) and identificamutations in type II procollagen (COL2A1) and identification of a fourth family with the COL2A1 Arg519Cys base
substitution using conformation sensitive gel electrophoresubstitution using conformation sensitiol
sis. Hum Mol Genet 1995;4:309-12.

8 Nakata K, Ono K, Miyazaki JI, et al. Osteoarthritis associated with mild chondrodysplasia in transgenic mice associated with mild chondrodysplasia in transgenic mice expressing a1 (IX) collagen chains with a
Proc Natl Acad Sci USA 1993;90:2870-4.

9 Fassler R, Schnegelsberg PNJ, Dausman J, et al. Mice lacking $\alpha 1$ (IX) collagen develop non-inflammatory degenerative joint disease. Proc Natl Acad Sci USA 1994;91:5070-4.

10 Briggs MD, Choi HC, Warman ML, et al. Genetic mapping of a locus for multiple epiphyseal dysplasia (EDM2) to a region of chromosome 1 containing a type IX collagen gene. Am f Hum Genet 1994;55:678-84.

11 Muragaki Y, Mariman ECM, van Beersum SEC, et al. A mutation in the gene encoding the $\alpha 2$ chain of the fibril-associated collagen IX, COL9A2, causes multiple epiphyseal dysplasia (EDM2). Nat Genet 1996;1:103-5.

12 Richard AJ, Yates JRW, Williams $\mathrm{R}$, et al. A family with Stickler syndrome type 2 has a mutation in the COL11A1 gene resulting in the substitution of glycine 97 by valine in gene resulting in the substitution of glycine 97 by

$13 \mathrm{Li} \mathrm{Y,} \mathrm{Lacerda} \mathrm{DA,} \mathrm{Warman} \mathrm{ML,} \mathrm{et} \mathrm{al.} \mathrm{A} \mathrm{fibrillar} \mathrm{collagen}$ gene COL11A1 is essential for skeletal morphogenesis. Cell gene COL11A1

14 Brunner HG, Beersum SEC, Warman ML, Olsen BR, Ropers HH, Mariman ECM. A Stickler syndrome gene is linked to chromosome 6 near the COL11A2 gene. Hum Mol Genet 1994;3:1561-4.

15 Vikkula M, Mariman ECM, Lui VCH, et al. Autosomal dominant and recessive osteochondrodysplasias associated with the COL11A2 locus. Cell 1995;80:431-7.

16 Briggs MD, Hoffman SMG, King LM, et al. Pseudoachondroplasia and multiple epiphyseal dysplasia due to mutations in the cartilage oligomeric matrix protein gene. Nat Genet 1995;10:330-6.

17 Cohn DH, Briggs MD, King LM, et al. Mutations in the cartilage oligomeric matrix protein (COMP) gene in pseudoachondroplasia and multiple epiphyseal dysplasia. $A n n$ NY Acad Sci 1996;785:188-94.

18 Baldwin CT, Farrer LA, Adair R, Dharmavaram R, Jimenez $S$, Anderson L. Linkage of early-onset osteoarthritis and chondrocalcinosis to human chromosome 8q. Am f Hum Genet 1995;56:692-7.

19 Kuivaniemi H, Peltonen L, Kivirikko KI. Type IX Ehlers-Danlos syndrome and Menkes syndrome: the decrease in lysyl oxidase activity is associated with a corresponding deficiency in the enzyme protein. Am f Hum Genet 1985;37:798-808.

20 Heikkinen J, Hautala T, Kivirikko KI, Myllylä R. Structure and expression of the human lysyl hydroxylase gene
(PLOD): introns 9 and 16 contain Alu sequences at the sites of recombination in Ehlers-Danlos syndrome type VI patients. Genomics 1994;24:464-71.

21 Hyland J, Ala-Kokko L, Royce P, Steinmann B, Kivirikko K Myllylä R. A homozygous stop codon in the lysyl hydroxylase gene in two siblings with Ehlers-Danlos syndrome type VI. Nat Genet 1992;2:228-31.

22 Berg ES, Olaisen B. Characterization of the COL2A1 VNTR polymorphism. Genomics 1993;16:350-4

23 Warman ML, Tiller GE, Polumbo PA, et al. Physical and linkage mapping of the human and murine genes for the $\alpha 1$ chain of the type IX collagen (COL9A1). Genomics chain of the

24 Mäkelä TP, Hellsten E, Vesa J, Alitalo K, Peltonen L. An Alu variable poly $A$ repeat polymorphism upstream of L-Myc at 1p32. Hum Mol Genet 1992;1:217.

25 Hellsten E, Vesa J, Heiskanen M, et al. Identification of YAC clones for human chromosome $1 \mathrm{p} 32$ and physical mapping of the infantile neuronal ceroid lipofuscinonsis (INCL) locus. Genomics 1995;25:404-12.

26 Brewton RG, Wood BM, Ren ZX, et al. Molecular cloning of the $\alpha 3$ chain of human type IX collagen: linkage of the gene COL9A3 to chromosome 20q13.3. Genomics 1995 30:329-36.

27 Steinlein O, Fisher C, Keil R Smigrodzki R, Vogel R. $D 20 S 19$, linked to low voltage EEG, benign neonatal convulsions, and Fanconi anaemia, maps to a region of enhanced recombination and is localized between $\mathrm{CpG}$ islands. Hum Mol Genet 1992;1:325-9.

28 Nedospasov SA, Udalova IA, Kuuprash DV, Turetskaya RL. DNA sequence polymorphism at the human tumor iecrosis factor (TNF) locus. F Immunol 1991;147:1053-9.

29 Gyapay G, Morissette J, Vignal A, et al. The 1993-94 Généthon human genetic linkage map. Nat Genet 1994;7:246339.

30 Martin G, Mann D, Carington M. Recombination rate across the HLA complex: use of microsatellites as a rapid screen for recombinant chromosomes. Hum Mol Genet 1995;4:423-8.

31 Briggs $\mathrm{MD}$, Cohn $\mathrm{DH}$. Length polymorphism within a complex dinucleotide repeat in the human decorin (DCN) gene. Hum Mol Genet 1993;7:1087.

32 Hecht JT, Wang Y, Rhodes C, Yamada Y. GT repeat polymorphism in the human proteoglycan link gene promoter region. Nucleic Acids Res 1991;19:6666.

33 Wang Y, Sadler L, Hecht JT. Polymorphic dinucleotide repeat in a cartilage matrix protein (CRTM). Hum Mol Genet 1992;1:780.

34 Csiszar K, Mariani TJ, Gosin JS, Deak SB, Boyd CD. A restriction fragment length polymorphism results in a nonconservative amino acid substitution encoded within the first exon of the human lysyl oxidase gene. Genomics 1993; 16:401-6.

35 Patel MS, Mankoo BS, Bruckell PM. A polymorphic microsatellite repeat is located close to the promoter region of the c-fgr proto-oncogene (FGR) at chromosome ip36.2p36.1. Hum Mol Genet 1992;1:65.

36 Litt M, Sharma V, Luty JA. Dinucleotide repeat polymorphism at the D11S35 locus. Nucleic Acids Res 1990;18: 5921.

37 Meulenbelt I, Droog S, Trommelen GJM, Boomsma DI, Slagboom PE. High-yield noninvasive human genomic DNA isolation method for genetic studies in geographically dispersed families and populations. Am $\mathcal{f}$ Hum Genet 1995; dispersed fam

38 Sambrook J, Fritsch EJ, Maniatis T. Molecular cloning: a laboratory manual. Vols I, II, III. 2nd ed. Cold Spring Harbor, NY: Cold Spring Harbor Laboratory Press, 1989

39 Lathrop GM, Lalouel JM, Julier C, Ott J. Multilocus linkage analysis in humans: detection of linkage and estimation of recombination. Am f Hum Genet 1985;37:482-98.

40 Ott J. Analysis of human genetic linkage. Revised ed. Baltimore: Johns Hopkins University Press, 1991.

41 Hanson IM, Gorman P, Lui VCH, Cheah KSE, Solomon E, Trowsdale J. The human $\alpha 2(\mathrm{XI})$ collagen gene (COL11A2) maps to the centromeric border of the major histocompatibility complex on chromosome 6 . Genomics 1989;5:925-31. 